\title{
Overview of School Well-Being in Students with High Academic Achievement in Featured High School
}

\author{
Shofiyah; Rosdiana; Ajeng Ayushi Widiyani \\ Graduate Program in Psychology Profession, Universitas Persada Indonesia Y.A.I, Jakarta, Indonesia
}

http://dx.doi.org/10.18415/ijmmu.v6i6.1217

\begin{abstract}
The objective of this study is to look at the condition of school well-being in students who have high academic achievement and attend featured schools. The composition and learning style of students in featured high schools is different from other schools, because students who have high academic achievement usually have a high desire to learn. In addition, these students are in a learning environment with good academic grades and high achievement competition. Then, there is a condition where other students have the opportunity to take part in a championship or an Olympic. However, it will be a pressure when a student who usually participates in the activity is not given the opportunity to participate. This study uses qualitative method with case study research design. Researchers collected data from four students who had high academic achievement in top schools with different background in life. The general conclusion of this study is that students with high academic achievement in excellent schools may not necessarily have a good school. Moreover, the description of each subject shows varied results. This study examines the dimensions of having (school conditions), loving (social relations), being (selffulfillment), and health (health conditions). Through the implementation of this study, researcher expects that the welfare of all students will get more attention.
\end{abstract}

Keywords: School Well-Being; Academic Achievement; Featured School

\section{Introduction}

In school well-being, there are important dimensions for students in providing positive encouragement in achievement. School well-being is a school condition that allows individuals to satisfy basic needs including having (school conditions), loving (social relations), being (self-fulfillment), and health (health conditions) (Konu and Rampelä, 2002).

Achievement is a final goal for students since the student can demonstrate his/her abilities through these achievements. Research on school well-being in the past decade has become interesting and is considered increasingly important because it has close links with students themselves (Konu \& Rampelä, 2002). School well-being or welfare in schools, which includes teachers, teaching systems, ways of teaching, friendship, facilities, and also health, are considered necessary for the lives of students at school (Green et al., 2014). 
Through the improvement of these facilities and services, students are required to be earnest in undergoing education so that they can excel both academically and non-academically (Street, \& Burge, 2012). Development and improvement in the field of education in general only emphasizes building facilities, the comfort of a learning building, or laboratory improvements to improve student achievement (Donovan, 2013). In fact, it does not only cover that. Students need greater attention in terms of welfare needs such as comfort in the school environment and also good relations with teachers and friends.

Students who excel have a close relationship with school well-being. This is determined by student factors in achieving achievement. These factors are divided into two: factors and external factors (Slameto, 2003). Internal factors are factors that come from within students such as motivation, health, interest in talent, and self-concept. Conversely, external factors are factors that originate from outside the student such as the school environment, family, and also the community. According to Nasution (1992), external or external conditions can be conditioned by the teacher; for instance, teachers create activities that increase motivation, choose appropriate and enjoyable teaching methods and are appropriate to the stage of student development (Day \& Qing, 2009). It will all greatly affect student learning outcomes. Based on some of the theories put school environment where all of these factors are included in the aspect of school well-being.

The dimensions of school well-being are having (school conditions) which include material and non-material aspects which include the physical environment, subjects and schedules, punishment, and services in schools (Konu \& Rimpelä, 2002). Next is loving (social relations) which is the relationship between teacher and student, relationships with classmates, group dynamics, bullying, collaboration between school and home, decision making at school, and the overall atmosphere of the school (Konu \& Rimpelä, 2002).

Students usually get demands from parents and teachers. As what the headmaster of Cipedes High School mentioned in an interview with researcher, parents are often busier than their children. If their child gets a low grade, then the parent will get angry and give them punishment. If students perform well in school, there will be more pressure they will receive such as demands from schools.

What the guidance and counseling teacher mentioned above is not just an ordinary conversation. It is important to note because it turns out that not only children who have problems and difficulties in learning should be considered, but also students with high academic achievement who in this case have entered the superior high school. Students with good academic performance who attend excellent schools certainly have a higher pressure than students who attend regular schools.

The composition and style of learning in high schools is different from other schools since students with high academic achievement usually have a high desire to learn. In addition, they are in an environment that has good academic value and high achievement competition. So, if students are careless and unable to maintain their achievements, the title as an outstanding student will be won by other students. Then, there is a condition where other students have the opportunity to take part in a championship or an Olympics. However, it will be a pressure when a student who usually participates in the activity is not given the opportunity to participate.

This can be considered as student dissatisfaction. Student dissatisfaction with school can have an impact on poor performance and behavior in school; for instance, non-involvement until school drop-outs (Huebner \& McCullough, 2000). These burdens and demands are one of the characteristics of unfulfilled student welfare in school (school well-being).

Another problem for students who excel is their association with fellow friends. Not all highachieving children can socialize well with their friends in the school environment. That is caused by busy 
in learning and various championships and Olympics. It makes these students less socializing with their peers. Thus, some high-achieving children only prioritize the lessons they are going to take, focusing only on championships, the Olympics, and other academic activities which are only the main goals in their school environment.

After reviewing the problem of school well-being in school students, the subject that researchers will take for this study is students from high schools who have featured school status. High school is an institution that provides secondary education which is a continuation of 9-year basic education. At this level, academic competition will be higher among students because high school is an education level that will take students to the professional world or the more serious world of education.

\section{Research Method}

The subjects in this study were students who took studies at the eleventh grade of high school and attended high school which had the status as featured schools. Researchers took as many as 4 research subjects consisting of 2 (two) boys and 2 (two) girls, each of which had a good academic achievement.

The number of subjects in this study initially was four people. However, one subject could not express his/her feelings to the researcher. Thus, the data that this research requires is insufficient. Then, the subjects of this study were three people and one significant person in each subject; i.e. one person closest to the subject. It is with the consideration that the determination of the number of subjects can show a more complete picture of the description of the factors that influence school well-being.

This research was conducted in several different places. The study began on April 2, 2015. The selection of research sites is determined by agreement between the research subjects and researchers.

This research uses a qualitative approach; an approach that assumes that individuals are very instrumental in describing a situation and feelings which are manifested in the form of words (Moleong, 2006). Qualitative research is a method used to be able to reveal the complexity of the social reality under study and rely on the power of narration (Poerwandari, 2013).

The research design that will be used in this research is a case study. Case studies are a type of approach in research that examines one case intensively, in depth, in detail, and comprehensively. Case studies can be conducted on individuals as is commonly done by analytical psychologists, as well as groups such as those conducted by several anthropologists, sociologists, and social psychologists. In the case of research using this design, various variables are explored and browsed, including possible relationships between variables. Therefore, research on a case may lead to statements that are explanatory. However, this explanation cannot be raised as a generalization. The background of life and the environment of a narcotics addict, the internal life of a gang, the formation of militancy in a radical group, and the factors behind the high self-help development in a village, are examples of the topics covered in a case study.

In this study, researchers will use the type of interview with general guidelines in the form of indepth interview. In this case, the researcher asked questions about various aspects of the subject's life in full and depth. Thus, it is expected that the researcher will obtain data about the school well-being picture of outstanding students in featured and complete leading schools and obtain an in-depth picture of each of the school well-being factors that affect students based on theoretical references that guide the researchers. 
Interview guidelines are used to reveal data qualitatively. The data in qualitative research is broader and deeper given that this data is collected by the researcher until the researcher feels that it is sufficient. Interview guidelines are a list of questions or issues that researchers must explore for the subject during the interview process. Interview guidelines assist researchers in improving the understanding and systematization of interviews on each subject (Poerwandari (2013).

Observation sheet is made to make observations on certain objects in accordance with those proposed (Poerwandari, 2013). That includes description of the setting and atmosphere of the interview, the physical appearance of the subject, other parties involved or appearing in the observation setting, nonverbal communication with the informant, as well as specific things that happened during the interview. Through the use of observation sheets, recording of observations on each subject is expected to be more systematic.

In conducting interviews, it is necessary to record and transcribe verbatim (word for word). It was intended that researchers could obtain accurate research data (Poerwandari, 2013). Recording data during an interview is very important because the basic data to be analyzed is based on a "quote" from the interview results. Therefore, data recording needs to be done as well as possible. Interview recording can be carried out with a tape recorder or other recording device; for instance, through the voice recorder application on a smartphone and recording through the interviewer itself.

Besides, the researcher also made notes during the interview. This note is very helpful for researchers to help plan the next new question and helps researchers to find important points in the vocal cords so that it facilitates data analysis (Poerwandari, 2013). Therefore, the researcher will make notes in the interview process that will take place. Thus, data retrieval is in accordance with what is happening in the field.

To meet the validity of the data, this study triangulated with research sources. According to Sugiyono (2009), triangulation with sources means comparing and checking back information obtained through various sources such as documents, observations, archives, interview results, observations or also by interviewing more than one object that is considered to have a different point of view.

That includes interviews with people closest to the subject (significant other). Data triangulation is performed by comparing the interview data between subjects with significant others. This technique is suitable for researchers because researchers can observe school well-being students with high academic achievement in featured schools who then combine it with data from significant others. Thus, one case can be explored intensively, in depth, in detail and comprehensively.

\section{Research Results and Discussion}

\section{Subject I $(T)$}

Having (School Condition)

Going to a superior school makes subject I (T) feel confident that it will be easier to be accepted at your favorite college. $\mathrm{T}$ said that in terms of comfort, the school was included in the classification of comfort. $\mathrm{T}$ chose the school not only because it was a featured school, but also because $\mathrm{T}$ will be easier to get into state universities.

According to $\mathrm{T}$, the subject material given by teachers at the school is lagging behind other schools. T often equated notes with friends at other high schools who were also in Tangerang. However, 
$\mathrm{T}$ found that it was far different; the notes $\mathrm{T}$ had were far enough behind. Apart from that, the subject said that the school was a school that was quite comfortable, with a large building that was enough to accommodate many students. Then, the class conditions are also comfortable for the learning process. However, $\mathrm{T}$ had complained about problems in the classroom where the air conditioner was not functioning properly and this disrupted the continuity of the learning process.

The subject is very fond of subjects related to science, especially chemistry so that $\mathrm{T}$ has a good relationship with the subject teacher. Moreover, the subject also took part in the chemistry Olympics; it is just that $\mathrm{T}$ has not become the champion. The subject said that T's brother had the same favorite subject, chemistry.

Related to school selection, the subject's parents play more roles in decision making. Even so, T admitted not to regret the decision. T thinks that there are still other schools that are better quality than their schools.

According to T, although the school is a featured school, there are some shortcomings that need to be fixed. The teaching system is what most needs improvement. According to subject I (T), the teaching system in the school is in the poor category. There are so many teachers who do not provide materials that fit the needs of students. The presence of the teacher can be counted on the fingers. In addition, school assignments take up a lot of student time.

According to $\mathrm{T}$ the teaching system of teachers in his school is not good because there are still many teachers who register their children in the school. Thus, it creates an unfair situation when teaching and learning. Even so, the subject felt that not all teachers' children got leaked questions during the exam because their classmates were children of very strict teachers.

Regarding the information on the competition or the Olympics that $\mathrm{T}$ attended while at school, $\mathrm{T}$ argued not to get the latest information. So, one time, $\mathrm{T}$ had searched for himself information about the Olympics that $\mathrm{T}$ was going to take part in and this made $\mathrm{T}$ difficult.

$\mathrm{T}$ claimed receive lacked guidance from the teachers at the school. So, $\mathrm{T}$ must find all the information alone. $\mathrm{T}$ admitted that the classmates were not very pleasant because $\mathrm{T}$ felt that those friends were not serious about the assignment given by the teacher. This certainly became a special pressure for $\mathrm{T}$. $\mathrm{T}$ also had time to cry because $\mathrm{T}$ was upset with the behavior of friends at a school activity because $\mathrm{T}$ was the secretary of the event at the time. Since the friends have less responsibility for the tasks assigned by the teacher, $\mathrm{T}$ feels less trusting of these friends in these activities.

However, T acknowledged that the assignment the teacher gave was still in a standard size. It was only a few times he got so many assignments that $\mathrm{T}$ had difficulty doing the work. Then, $\mathrm{T}$ also felt disappointed when there was a UAS leak event that occurred in the class. According to T, the lattice of the matter had indeed been distributed in advance.

In general, $\mathrm{T}$ has a pretty good quality dimension of having (school conditions). School $\mathrm{T}$ has tried to provide good service to students. However, T also gave input so that the school would pay more attention to dirty class conditions because class pickets did not run properly. However, overall $\mathrm{T}$ felt that the condition of the school was good enough for T to learn and achieve. 


\section{Loving (Social Relation)}

In the loving dimension (social relations), the subject is quite good. It is just that $\mathrm{T}$ has problems in social relationships between friends. $\mathrm{T}$ lacked close friends. In fact, $\mathrm{T}$ claimed that since middle school $\mathrm{T}$ had no close friends and called him/herself an anti-social being.

The subject had experienced things that made him/her feel so depressed that he/she cried unbearably. I felt to be used as a tool to free classmates from cheating. T borrowed a note from a friend who was attending another high school in Tangerang. T obtained more complete study material from T's own notes. However, it was used as an alibi for T's friends who cheated until $\mathrm{T}$ was called to the principal's office.

Then, the subject seemed to have a pretty good relationship with the teacher. $\mathrm{T}$ never had a significant problem with the teacher. It is just that $\mathrm{T}$ feels that the teacher must improve his/her work system and also not send his children to the same school. Thus, decision making will be fair and there are no conditions where parents defend their children. It should not be like what has been done by one of the teachers where the teacher only provides the best service to the teacher's child. The subject has a close relationship with the teacher, so $\mathrm{T}$ found it difficult to ask about the subject matter that was left behind.

Then in the subject's relationship with parents, the subject has a few obstacles. The subject is less able to express the subject's heart to parents as about the subject of college that the subject wants.

In general, $\mathrm{T}$ has a poor-quality picture in the loving dimension. $\mathrm{T}$ is less able to socialize with friends, teachers and parents. $\mathrm{T}$ revealed that this had been a problem since $\mathrm{T}$ was in junior high school. For example, $\mathrm{T}$ is difficult to express wishes clearly to parents.

\section{Being (Self Fulfillment)}

The subject claimed not to participate in the organization's activities at school because $\mathrm{T}$ did not like it. Not only because of that, the subject claimed to be afraid afraid of the seniority that existed during the training. T said that the Basic Leadership Training was a cruel activity.

The subject participated in an English language extracurricular activity at school. However, T feels disappointed since not to get guidance from the teacher in this participation. Then $\mathrm{T}$ also said that the Basic Leadership Training included heavy school organization activities.

The subject said that there was no Guidance and Counseling teacher in his school, even though T often felt needed advice from the Guidance and Counseling teacher about the majors and problems around the school. It is the same as what was stated by SO regarding Guidance and Counseling teachers whose whereabouts are unknown. In addition, there is no assignment of roles to class X and XI students.

In general, the subject has a good picture on the dimension of being, but $\mathrm{T}$ is less able to follow activities that have seniority or high discipline such as the Intra-School Student Organization.

\section{Health}

For this dimension, the subject has a pretty good condition. However, the subject tells about dirty classroom conditions. This is because the class picket is not going well. Thus, students in the class are sometimes given a reprimand by the picket teacher. 


\section{Research Findings from Significant Person Subject I (AS)}

AS is the closest person to the subject where she is the subject's mother. AS is a mother who is very concerned about her children, especially in the field of education. So, she always pays attention to the T value in school. According to the US, T is indeed reserved and likes to be alone. In addition, the US said that $\mathrm{T}$ was very difficult to be invited to discuss so that the US found it difficult to know T's wishes.

According to the US narrator the subject had no problems at school because she had never heard the report that $\mathrm{T}$ had difficulty at school. Then, the US also said that $\mathrm{T}$ often remained silent in room, $\mathrm{T}$ preferred to listen to music and study in the room. US says that T is a good student but it is difficult to give $\mathrm{T}$ input.

\section{Research Findings from Significant Person Subject I (SO)}

According to $\mathrm{SO}, \mathrm{T}$ is a quiet person even very quiet and does not have close friends. Therefore, she tried to approach $\mathrm{T}$ in order to be close friends with $\mathrm{T}$. According to SO, T is a smart person and also cool to talk to about everyday things. However, T lacks more courage. Therefore, when SO invited $\mathrm{T}$ to chat, $\mathrm{T}$ welcomed her happily.

SO recognizes that $\mathrm{T}$ is a smart person. She gave a thumbs-up and said that $\mathrm{T}$ was truly an accomplished child. According to SO, the subject $\mathrm{T}$ has loving qualities with poor friends.

\section{Subject II (A)}

\section{Having (School Conditions)}

A said that the teacher at school explained the lesson to the method in general but with different teaching techniques. With these different teachings, A feels no difficulty in learning activities because the teacher's teaching style is still in accordance with A's learning style. However, changes in the educational curriculum are quite influential in school learning activities. The change of the curriculum in KTSP to the 2013 curriculum for A is not yet fully understood, especially the current curriculum, the 2013 curriculum. It is because the teacher teaching system still uses the teaching system used for the KTSP curriculum.

However, changes in the assessment of students in the 2013 curriculum are sufficiently understood by $\mathrm{A}$. This shows that $\mathrm{A}$ is very concerned about school assessments to students which is a benchmark for student achievement. A felt that in general the school environment was good so he felt comfortable with the existing facilities. However, according to A, there are some school facilities that are less comfortable namely the school canteen. The canteen at the school is not too big. Many seniors eat there so A feels uncomfortable because they are not the same age. So, every time A goes to the cafeteria, A always brings the food to eat in class.

Then A said that the school gave strict punishment to students related to violations of the rules in the school. At the school, the punishment does not recognize the term bargaining. A clear and firm legal system is a concern for A because the school does not hesitate to drop out students who have problems in school. A also considered that the facilities in the school were good including the system, teachers, and school programs. When asked to provide input to the school environment, A emphasized that the school environment was good, but it needed to change individuals who were in the school. 
In general, A has a good picture in the dimension of having (school services). This was shown by A with not much complaining about the services the school provided to students. A also understands punishment in school and has a good knowledge of teacher assessments of students as a school benchmark to give the predicate student achievement.

\section{Loving (Social Relations)}

In the loving dimension (social relations), A claimed to be less close to friends at school. A regards friends only as a complement. This is shown by A by not liking hanging out with friends at school even if only during breaks or outside school hours. Even A is lacking in communication except learning problems and just chatting with A's peers. However, when friends have difficulty in learning and want to ask deeper questions about lessons and come to A's home, A does not hesitate to accept and teach material that is not yet understood by friends in A's own home.

Then A prefers to withdraw from friendship because character A is less like socializing with friends. A also said reluctance to join together with friends at school and outside school. It is because A was educated from a family environment where after returning from school, A had to go straight home and not be allowed to go anywhere first. Finally, the character is recognized by A until now.

Different thing is shown by A when socializing with teachers at school. A is more proactive in socializing with teachers and A does not hesitate to ask questions about subjects that are not well mastered. The teacher also gives a good response to A. However, sometimes A does not dare to ask certain teachers because A considers the teacher's character to be uncomfortable when learning, especially when students do not understand the lesson.

In making achievements, A felt that the role of parents was very influential in motivating $A$ to study hard at school. Parent A gives good direction without burdening A for achievement. Parents A give enough advice so that A always learns, prays and is not easily satisfied with the achievements now. Then, A's parents always remind A to always study the study questions so that A can easily take the exam. Then, parent A provides another motivation by reminding A to be one level ahead of the classmates at school.

In general, subject II (A) has a sufficient picture in the loving dimension. Relationships with teachers and parents can be said to be good. However, in friendships, A is not overly concerned and chooses to withdraw from social relations with friends. This is influenced by the upbringing and family habits of A. So, A feels that the relationship with friends is carried out only as needed.

\section{Being (Self Fulfillment)}

Subject II (A) has sufficient quality dimensions of being. A withdraws from every activity held by the school to students. A reasoned that school activities were not pleasant. Moreover, joining the organization means that students have additional schedules outside of school. Then, A felt that the role of the Guidance and Counseling teacher in the school was in developing students as they should. The Guidance and Counseling teacher at school is not functioning well compared to A sister's Guidance and Counseling teacher at another school.

According to A, the school's effort to meet the needs of students in participating in the Olympics was good enough. Routine activities such as the National Science Olympics are always proposed by 
schools in the participation of these activities. However, students must seek information independently for the Olympics from outside the school such as state universities.

Subject II (A) has sufficient description in the dimension of being. School A has provided infrastructure to meet the needs of students to participate in every activity to support student learning activities. However, A was more withdrawn from participating in activities held by the school. However, schools are also not optimal in meeting the needs of students, especially in coaching by Guidance and Counseling teachers. A felt that the performance of the BK teacher was not as what was supposed to be. However, this does not affect $\mathrm{A}$ in achievement because $\mathrm{A}$ has never had a problem or consulted with a BK teacher.

\section{Health}

Subject II (A) said that health facilities and infrastructure in schools were good enough for students; for instance, clean and spacious school toilets. A said that health is an important factor for him in achieving achievement. If A has too many activities, A will get tired easily, which in turn lowers A's health. Thus, it causes A to get sick and not go to school for a long period of time which will affect learning achievement A. Therefore, to avoid deterioration in health is to avoid school activities that consume too much time and energy.

In general, subject A has a sufficient picture in the health dimension, the school has provided basic needs for health; for instance, clean and spacious toilet. However, school activities that require considerable time and energy can reduce the quality of health. However, A has own way to maintain health. A claimed to deliberately avoid school activities with the reason to maintain good health conditions because the subject has a medical history that prevents A from doing strenuous activities that will interfere with learning if A's health declines.

\section{Research Findings from Significant Person Subject II (AD)}

The significant person subject II (AD) is the closest relative of subject II (A), AD reveals that A has a cool and relaxed character. This is said by AD because the character has become an innate nature of the family. A often told stories with $\mathrm{AD}$ but it was just a chat. Then the AD salute and be proud of the intelligence that $\mathrm{A}$ has. A also prefers to shut himself up and study in the room rather than hanging out with his friends.

Later, $\mathrm{AD}$ revealed that $\mathrm{A}$ was very easily ill when too tired. If $\mathrm{A}$ is sick, another illness will come. This also causes A to dislike doing things that make A easily tired; for example, sports and school activities that consume a lot of time and energy.

$\mathrm{AD}$ also revealed that the role of parents is very influential on the achievement of $\mathrm{A}$. $\mathrm{A}$ has a good relationship with their parents. A parent always gives enthusiasm and motivation. A's parents also never demanded A to excel. However, they encourage and strengthen A's heart to study harder so that A can perform even better. Then the $\mathrm{AD}$ also added that A rarely left the house except for group work or activities related to other learning activities. 


\section{Subject III (B)}

Having (School Conditions)

Subject III (B) claimed that the condition of the school in general was good and very supportive to meet learning activities. However, there are still a number of school facilities that must be considered and immediately repaired to create a comfortable learning environment. B revealed that some of the facilities in class did not function properly. However, classroom conditions are not a major factor in meeting their learning needs.

Then, B also revealed that the teaching conditions of teachers in schools were generally good. However, B regretted that there were some teachers who lacked discipline in teaching hours. B felt that some of the teachers at his school did not teach on schedule as they should. Some teachers often rarely enter the classroom to teach directly.

Besides that, B feels very happy with the teachers who teach according to the existing schedule. B felt that the class teachers were very concerned about students in providing material by giving a good explanation. B is worried that when the next grade rises B will not get the same teacher as at the current class XI. B also very much agreed with giving many assignments from the teacher. B said the assignment by the teacher was good enough. This, according to B, really helps students, especially in the practice of students to learn.

In general, B has a good picture of the dimensions of having (school conditions). This is indicated by complaints about the condition of the school that does not really make it difficult for B to learn. However, B gave little input that the library and class facilities needed to get the attention of the school. However, overall B feels good about this dimension.

\section{Loving (Social Relations)}

Subject III (B) is not much different from Subject II (A) and Subject I (T) in terms of friendship. $\mathrm{B}$ does not like to hang out with friends even for playing or just refreshing. B prefers to gather with family and prefers to go alone. B also has no close friends. It is because B withdrew from friendship.

Even though B does not like hanging out with friends, it does not mean that B is not good at making friends. It is revealed that B was easy to make new friends. In friendships, B regards friends more as a rival who can at any time take the position he has now. B sometimes feels scared and worried when friends start to look more diligent to learn, which finally makes B depressed with the situation.

Then B prefers to avoid one class with friends when taking tutoring outside of school. B revealed this because B felt pressured by smart friends. B is more easily stressed when class with smart kids. Therefore, B will choose another tutoring class where the class is attended by children outside school. That way, B will feel comfortable following the tutoring.

As with the teacher, B has a better relationship with the teachers at school. B is often trusted by teachers to explain or make a list of other student's grades. In fact, B is close to the teacher who motivates $\mathrm{B}$ to be more active in learning.

Furthermore, B's relationship with parents becomes the dominant factor in B decision making in every activity in the school and outside of school. B really looks forward to the moment with family when the school holidays have arrived. This is because B does not live in the same house as B's parents, where 
B lives in grandmother's house. B felt the need to rest for a while after studying for 1 week at school. B does it by gathering with parents.

Based on the above explanation, the loving description of subject B can be considered sufficient. B has not been able to socialize properly because B still withdraws to join friends even though B can actually make friends easily. On the other hand, B has a good relationship with teachers and parents. B is liked and trusted by teachers at school which indicates that B has good loving qualities with teacher. Similar to B's parents, B prefers to be with family compared to friends. Gathering with parents is always B's desire every school weekend. It also indicates that B has a good loving quality with parents.

\section{Being (Self Fulfillment)}

On the dimension of being, subject III (B) follows a number of school activities to support abilities outside of academics. Even the school has provided good programs for students in selffulfillment provided through school organizations. The school organization that B followed was Rohis. The reason B joined Rohis organization was a desire from conscience. B really likes religious activities.

Then, in the Olympics activities, B admitted that the school was very enthusiastic in finding information related to the Olympic competition. However, the subject also said that after information related to the Olympics activities was received, the school paid less attention to the guidance and coaching for students who would take part in the Olympics. In fact, B felt that there were teachers who did have excellent teaching skills. Sometimes the daily questions the teacher gave were similar to those of the Olympics. However, B felt that the teacher did not contribute to the Olympics. B certainly regretted this.

Furthermore, the school effort to fulfill students, especially coaching, is carried out by the Guidance and Counseling teacher. B said that the Guidance and Counseling teacher was only active for class XII students when students began to prepare to continue their studies to college. Seeing this, B revealed that the role of the Guidance and Counseling teacher was very important to be given from the beginning of entering school. Students need to be guided from the beginning to know the learning objectives. So, in undergoing the learning process, students have clear goals.

Then in the majoring class at school, B claimed that the school implemented a new method for classifying students according to their talents and interests using the fingerprint test method. In the process, students must consult with a psychologist but the consultation is still very limited. Therefore, B felt the need for the role of the Guidance and Counseling teacher in terms of managing talent and interests. B also regretted that the role of the Guidance and Counseling teacher did not appear as it should. In fact, while B was studying at the school, B had never seen the Guidance and Counseling room at school.

Based on the explanation above, subject III (B) has sufficient description on the dimension of being. B actively participates in school activities by joining organizations in school. Then, the subject also revealed to the school to pay attention to student coaching, especially the Guidance and Counseling teacher who had to improve the performance and quantity at school. However, the lack of guidance and counseling teachers is not a significant influence in achieving achievement.

\section{Health}

In this dimension Subject III (B) revealed that the school had improved its health services. This is demonstrated by renovating toilets for the convenience, cleanliness and health of students. Previously, the 
condition of school toilets was very dirty. In addition, the fulfillment of student health is also demonstrated by the provision of good canteen facilities. B also revealed that there was a ban on selling certain types of food and drinks in the canteen. This is a form of school protection to ensure the health of students from food and drinks that are harmful to students.

In general, subject III (B) has a good picture of the health dimension. It was shown by B by revealing that school had given good health rules and facilities to its students in supporting teaching and learning activities in school.

\section{Research Findings from the Significant Person Subject III (S)}

$\mathrm{S}$ is a girl who is very close to B. S always gives encouragement and support for achievement to $\mathrm{B}$. $\mathrm{S}$ is also very concerned about how to learn $\mathrm{B}$ intense so it is normal that $\mathrm{B}$ always gets a champion in school.

Then in the selection of superior schools. B revealed that the $\mathrm{S}$ school selection was a joint decision between $\mathrm{B}$ and $\mathrm{S}$. There was always communication with $\mathrm{B}$ and $\mathrm{S}$. Furthermore, $\mathrm{S}$ strongly supported B's willingness to continue education to the medical faculty. S is very proud of S for B's achievements so far. At the time of the interview, S was very happy and radiant when asked about B. B's achievement was evident from S's response when B said it. S immediately showed a happy expression by laughing and smiling shyly.

\section{Subject IV (G)}

\section{Having (School Conditions)}

Subject IV $(G)$ revealed that the conditions at school according to $G$ were less comfortable. It is because the condition of school $\mathrm{G}$ is not shady. So, during the ceremony, many students complained of being overheated. Some students often leave the ceremony complaining of dizziness due to the heat too long in the ceremony field.

Then, G complained about discipline in dressing, especially the senior, who did not set a good example. Besides that, the attitude of the seniors was less pleasant and cynical. In addition to being here, there are a number of senior brothers who blackmail younger student. $G$ also said that seniority in school was still very much exist. It is shown in the condition where the younger class must say excuse me if passing in front of the senior brother. If they do not, they will be fooled by that senior. However, G revealed that in terms of facilities, class conditions were good enough and comfortable to support student performance.

Then, from the teacher aspect, $\mathrm{G}$ admitted to having good quality and friendly teachers. $\mathrm{G}$ often chats with teachers at school. Then, $\mathrm{G}$ is also trusted by the teacher and friends to be vice-class leaders. This position, of course, became additional tasks for $\mathrm{G}$, such as checking teachers who had not yet entered class, taking attendance books, and other assignments. However, $\mathrm{G}$ was pleased with this additional assignment. Sometimes, when there are a lot of school assignments, $G$ feels burdened with these additional assignments. In addition, the class president lacks a sense of responsibility.

However, not all teachers can be kind. G says that there are still fierce teachers; for example, when class sounds noisy. In the beginning, the teacher gave a verbal warning. However, if it has gone too far, the teacher takes physical action on the student and the student is reported to the Guidance and Counseling teacher. $G$ also revealed that the noisy classroom conditions really disturbed $G$ through learning activities. As vice-chair of the class, $\mathrm{G}$ felt he had a responsibility to make the class conducive by 
reprimanding friends. Even so, G deplored the attitude of friends who were not happy with G's attitude. G also expressed his disappointment with the class president who seemed indifferent to the condition of the class like that.

Then, $\mathrm{G}$ also complained about giving too many assignments from the school. Sometimes, $\mathrm{G}$ also avoids many of these tasks by planning not to enter class. $G$ was rather disappointed with the assignment of many assignments from the teacher because sometimes after students had finished working on the assignments, the teacher did not check it. $\mathrm{G}$ was disappointed because he had completed the task to the maximum and had to stay up all night. Furthermore, the complaint $G$ in assigning is the way to collect tasks. The teacher at the school instructs students to collect school assignments by e-mail. This method according to $\mathrm{G}$ troubles students in learning.

Next is about punishment in school. School G has some very strict rules. G said that students should not date at school. If a student is caught dating, the student will be humiliated at school and will be expelled from school. One time, a schoolmate was expelled from school because of courtship and doing something that is not good. This greatly influenced $\mathrm{G}$ in school to be better.

In general, subject IV (G) has an adequate picture of the quality of having (school conditions). $G$ has a good relationship with teacher but what becomes complaint at school is the attitude of the older sibling who is not good at treating classmates so that it seems terrible to G. Furthermore, also G is less comfortable with noisy classroom conditions.

\section{Loving (Social Relations)}

G was very disappointed with the actions carried out by friends who mocked $G$ about $G$ parents' divorce. $\mathrm{G}$ claimed to be so depressed that $\mathrm{G}$ had to be the most outstanding student in order to be able to prove that $\mathrm{G}$ was able to be the best. The friendships $\mathrm{G}$ has formed in class sometimes go through bad conditions. That is caused by something that has become a habit or culture in school. If you are friends with 1 person, that person cannot be friends with others. Therefore, $G$ feels that this friendship is unhealthy, but $\mathrm{G}$ has no other choice and chooses to make friends anyway.

Mocking and criticizing from friends motivated $\mathrm{G}$ to get up and become a champion in school. For G, nothing is impossible, everything can be done as long as it is actively trying. Even though G does not have complete parents, G can achieve the highest rank in school.

When saying the things that made G sad, G was moved to tears so that G's voice sounded heavy. It was clear that this was burdensome to $G$. Yes, $G$ does not live in luxury or lack but $G$ always tries not to burden mother. To the extent that $\mathrm{G}$ is willing to not snack, do not play to the mall, and shop like a child G's age. G has one hope and goal, which is to make mother not feel burdened by material problems.

$\mathrm{G}$ has strong competition in class. So, $\mathrm{G}$ felt motivated to always study hard. There are times when $G$ 's friends ask for a cheat on $G$, but $G$ is a person who is afraid of competition. Thus, $G$ chose not to cheat. However, if there are friends who want to ask questions, G really appreciates by teaching the knowledge $\mathrm{G}$ has.

Not just a matter of cheating, $\mathrm{G}$ also has problems with friends who are often noisy in class. $\mathrm{G}$ had scolded his friend who was noisy in class during class, but instead $\mathrm{G}$ was ridiculed from other friends.

Apart from that, $\mathrm{G}$ has a good relationship with teachers and parents. This is evidenced by the teacher's trust which makes $G$ the vice-chair of the class. However, G's position as vice-class leader 
sometimes kept $\mathrm{G}$ busy because $\mathrm{G}$ had to take responsibility for the class because the class president was less trustworthy. He also became a forum for the aspirations of classmates regarding class problems.

$\mathrm{G}$ said that the relationship with parents is very close. This can be seen from the habit of $\mathrm{G}$ to tell everything that happened to parent or mother. Moreover, $\mathrm{G}$ often asks for parent's opinion in any case.

Overall $\mathrm{G}$ has a pretty good loving dimension quality. It is just that $\mathrm{G}$ has obstacles in relationship with friend. $G$ felt pressured by the mockery that was hurled by friend so that it had made $G$ reluctant to go to school. On the other hand, G has a good relationship with teacher because $\mathrm{G}$ has the trust to carry out duties as vice-chair of the class and also a good relationship with mother. G often tells complaints and also discuss things with mother (AM).

\section{Being (Self Fulfillment)}

In this dimension, subject IV $(\mathrm{G})$ has a good quality in which $\mathrm{G}$ participates in many activities made by the school. However, G did not join the student council and other organizations because of the estimated time and distance of the school to home which is quite far. Moreover, student council activities spend more time until the afternoon at school. Meanwhile, the top street of Bogor always applies the open and closed lanes. If $\mathrm{G}$ comes home too late, $\mathrm{G}$ will have difficulty finding access to go home. $\mathrm{G}$ is an active student and it can be seen from the photos displayed on the walls of G's room. The photos bear witness to the achievements that $\mathrm{G}$ gained.

In addition to participating in the Olympics, $G$ was also trusted as the class vice president. $G$ attended the Olympics appointed by the teacher, so G was a chosen student. G said that the Guidance and Counseling teacher helped $G$ greatly in the selection of the Olympics. $G$ had a pleasant experience while attending the Olympics.

G did not attend the student council activities for fear of lack of security when traveling home at night. G's mother and family also worried that $\mathrm{G}$ came home too late at night. However, $\mathrm{G}$ actually has a great interest in the student council's participation.

In general, $\mathrm{G}$ has a pretty good quality dimension of being, only $\mathrm{G}$ does not attend student council activities at school for reasons of distance and time. Beyond this, the quality of the subject's dimension is quite good.

\section{Health}

Subject IV (G) said that the health support facilities and infrastructure provided by schools for its students were good enough. The School Health Unit in the school is always in a clean and comfortable state. It is not surprising that many students come to visit the School Health Unit. In fact, there are students who pretend to check their health and then sleep in the School Health Unit.

The condition is different with school toilets. G strongly complained about this health facility. The toilets in the school are very dirty. Although $G$ wants to go to the toilet, $G$ restrains the desire as much as possible to avoid the dirty toilet. $G$ will only use the school toilet if it is already in an urgent situation.

Based on the information described in subject IV (G) above, the picture of quality in the health dimension is quite good. The school has provided good health facilities to ensure health services for 
students, but on the other hand the school also pays little attention to the cleanliness of toilets so that students can use these facilities as they should.

\section{Research Findings from Significant Person Subject IV (AM)}

$A M$ is the figure of a woman who is very close to $G$. AM revealed that $G$ is not too sociable with friends and friends too freely. AM also expressed very proud of the achievements achieved G so far. AM also always gives support and encouragement to $G$ in achievement and continues to provide encouragement for the achievement of $\mathrm{G}$.

AM also said that $G$ never demanded new things, such as snacks or new cellphones. $G$ has persistence to excel even in unfavorable conditions, especially family problems. However, that did not dampen $\mathrm{G}$ to always pretend. AM is very proud of $\mathrm{G}$ who has many achievements.

\section{Conclusion}

Conclusions for the description of school well-being in students with high academic achievement are varied. Subject I (T) has unfavorable school well-being conditions, subject II (A) has good school well-being conditions but there are some aspects that do not get enough attention from the subject, subject III (B) has good school-being conditions who are not good, and subject IV (G) has a poor condition of school well-being.

Subjects I (T), III (B), and IV (G) have poor quality of having (school conditions). According to the subject, schools still have to improve their quality again. For instance, subject I (T) said that the teaching system in school still had to be considered because there were still many teachers who did not attend classes but gave quite a lot of assignments. In addition, hot class temperatures make it difficult to concentrate while studying.

Subject III (B) also tells the teacher teaching system that must be improved. When the teacher does not attend class to provide material, the subject feels disadvantaged. Then subject III (B) also said to have difficulty finding references for assignments in the school library because the library collects more novels than textbooks.

Subject IV (G) said that the condition of the school was indeed good but there was still something to be considered regarding facilities that did not meet the needs of students; for instance, dirty toilets, poorly maintained laboratory science and the completeness of practical tools, and also the lack of trees that make the school atmosphere hot. In fact, the subject said that during the ceremony some students left the ceremony due to dizziness.

For loving quality (social relations), subject I (T), subject II (A), subject III (B), and subject IV (G) have poor quality of friends at school. On average all subjects have problems with friendships. For instance, they are less able to establish good relations with classmates. In addition, the characters of all subjects are less able to work in groups. So, when there are school assignments that require them to work in groups, they will feel pressured. According to the subjects, they prefer to work individually rather than in groups and the subjects feel that they are able to do everything themselves without the help of others.

But in loving (social relations) the subjects with teachers in schools are classified as good quality because the subjects can communicate well enough with the teachers. In fact, subject III (B) became a 
student close to several subject teachers. Similar to subject IV (G) who is trusted to be vice-chair of the class by homeroom teacher.

For loving quality (social relations) with parents, only subject I (T) has poor quality. T does not feel that parents give demands that make them feel bored.

In the dimension of being (fulfillment) the subjects showed sufficient quality because all subjects had participated in Olympic and other championship activities. However, all subjects showed a lack of quality in being (fulfillment) in organizational activities in schools. The subjects said that they had less interest in joining organizations in schools such as Intra-School Student Organization because the subjects did not want to take part in the Basic Leadership Training activities. However, subject IV (G) was not interested in joining the organization at school because they did not get parental consent with consideration of distance and access to go home.

In the dimensions of health, subject I (T), subject III (B), and subject IV (G) have good quality health because the subjects claimed learning styles and also the tasks of school did not make their health decline. All activities related to learning only make the subjects feel tired and bored, but the subjects can still tolerate it.

That is different from subject II (A) where the subject has poor health quality because physical condition is relatively weak. The subject also has a history of allergic diseases that easily recur when the subject is too tired. Thus, subject II (A) complies with reducing exhausting physical activity and more study at home.

\section{Implication}

Based on the findings of research that researchers have obtained, the implications of this research are to provide benefits for developing science, educational psychology and also general psychology. It is also a comparison and information material for educators, parents, and students about school well-being and also as input for educational practitioners.

\section{References}

Day, C., \& Qing, G. (2009). Teacher emotions: Well being and effectiveness. In Advances in teacher emotion research (pp. 15-31). Springer, Boston, MA.

Donovan, M. S. (2013). Generating improvement through research and development in education systems. Science, 340(6130), 317-319.

Green, C. P., Navarro-Paniagua, M., Ximénez-de-Embún, D. P., \& Mancebón, M. J. (2014). School choice and student wellbeing. Economics of Education Review, 38, 139-150.

Huebner, E. S., \& McCullough, G. (2000). Correlates of school satisfaction among adolescents. The Journal of Educational Research, 93, 331-335.

Konu, A.l; Lintonen, T. P, \& Rimpelä, M. K. (2002). Factors Associated with Childrens' General School Well-Being. Health education research, Vol 17 (2), 155-165. 
Nasution, N. (1992). Psikologi pendidikan.Jakarta: Dikti Depdikbud. hlm.35.

Poerwandari, E. K. (2013). Pendekatan kualitatif untuk penelitian perilaku manusia. Depok. LPSP3 UI.

Slameto. (2003). Belajar dan Faktor-Faktor yang Mempengaruhinya, Jakarta: Rineka Cipta.

Street, D., \& Burge, S. W. (2012). Residential context, social relationships, and subjective well-being in assisted living. Research on Aging, 34(3), 365-394.

\section{Copyrights}

Copyright for this article is retained by the author(s), with first publication rights granted to the journal.

This is an open-access article distributed under the terms and conditions of the Creative Commons Attribution license (http://creativecommons.org/licenses/by/4.0/). 